\title{
Competitiveness and Comparative Advantage of Cocoa Production in Southwestern Nigeria: A Policy Analysis Approach
}

\author{
Oluyole, Kayode A. \\ Economics Section, Cocoa Research Institute of Nigeria, Nigeria
}

Copyright $(2018$ by authors, all rights reserved. Authors agree that this article remains permanently open access under the terms of the Creative Commons Attribution License 4.0 International License

\begin{abstract}
The study investigated the competitiveness and comparative advantage of cocoa production management systems in the study area. The project was carried out among cocoa farmers in Ondo and Osun States of Nigeria. Simple random sampling technique was used to collect data from the farmers. Data were collected from the respondents with the aid of structured questionnaire and the data obtained from the questionnaire were analysed using Descriptive analysis, Private Profitability, Private Cost Ratio, Social Profitability and Domestic Resource Cost. Most (63.64\%) of the respondents are of age 50 years and below while majority $(84.09 \%)$ of the farmers are having formal education. However, $87.50 \%$ of the farmers are having farm size 5 hectares and below. The result of Private Profitability was positive in all the three management systems while the Private Cost Ratio (PCR) was less than one in all the management systems considered. The result of Social Profitability was positive while that of Domestic Resource Cost (DRC) was less than one in all the production management systems. The study concluded that cocoa production is highly competitive in the study area.
\end{abstract}

Keywords Cocoa, Production, Competitiveness, Comparative Advantage, Policy Analysis Matrix

\section{Introduction}

The importance of cocoa to most developing countries cannot be over-emphasized as cocoa is produced by most developing countries across Asia, Africa and Latin America all of which are Tropical or Semi-tropical areas (Akinbola [1]; Olayide and Falusi [2]; Oyinloye [3]). The cocoa market is characterized by a heavy concentration of production in West Africa (Abbot [4]; Ajayi and Okoruwa [5]). It is estimated that $90 \%$ of world cocoa production comes from smallholdings and that there are currently 2.5 million cocoa smallholders whose average farm yield is $350 \mathrm{~kg}$ per hectare (Titilola [6]; Asare [7]).

Cocoa provides livelihoods for millions of people in over 50 countries in Africa, Latin America, the Caribbean and Asia (Kaplinsky [8]). During the crop years from $1998 / 1999$ to $2007 / 2008$, global cocoa production increased from around 2.8 million tonnes to 3.7 million tonnes, with an average annual growth rate of 2.7 percent. Consumption showed similar patterns, with an average annual increase of 2.9 percent, from 2.9 million tonnes to 3.7 million tonnes (Kaplinsky [8]). However, farming and harvesting of cocoa pods, and the extraction, fermentation and drying of cocoa beans necessarily occurs on or very near the farm, and has few scale economies.

Nigeria is the world's $4^{\text {th }}$ largest cocoa producer after Ivory Coast, Ghana and Indonesia, producing around 250,000 tons a year (Mejabi [9]). Exports of cocoa products from Nigeria, was $\$ 822.8$ million in 2010 . This represents about 35 percent of the $\$ 2.32$ billion earnings from non -oil exports in 2010 for Nigeria. Main importers of cocoa from Nigeria are Holland, United States, Germany, Britain and Brazil (Mejabi [9]).

In Nigeria, cocoa has been the main agricultural stake of Nigerian economy until early 1970s when the crude oil was discovered in the country in large quantity. Cocoa has remained a valuable crop and a major foreign exchange earner and agricultural commodity export of Nigeria However, cocoa production in Nigeria has been faced with a lot of problems such as problem of depleted soil fertility, poor control of pests and diseases, poor maintenance of cocoa farms, lack of credit facility to support farm production as well as lack of agricultural inputs such as fertilizer (Oluyole, et al. [10]). In response to the problems, the Federal Government of Nigeria established National Cocoa Development Committee (NCDC) in 2000 with the aim of revamping Nigerian cocoa sub-sector.

The continuous increase in cocoa production will 
depend on the international competitiveness and the effects of policy intervention. The removal of all forms of tariffs will change the structure of economic incentives. This, in turn, will cause major adjustments in the pattern of production, allocation of resources and trade flows. The analysis of competitiveness and comparative advantage will provide an indication of the effects of policy. Comparative advantage of a country in a commodity usually results from relative superiority in resource endowments required by the commodity. It puts the country in a vantage position to specialize in the production of the commodity. Competitive advantage is created through appropriate combination of knowledge and other critical resources to gain significant share of the world market for a particular commodity. Competitive environment and the capability of firms in the industry to innovate and improve their technologies contribute to the achievement of competitive advantage. The use of comparative advantage analysis covers not only the on-farm production but incorporates downstream collection, processing and wholesaling activities as they relate to a particular commodity.

Policy Analysis Matrix (PAM) is an accounting identity used to reflect the private and social cost and prices of a representative business entity. PAM framework uses detailed information from a production budget as well as other processing affiliated costs related to the production and marketing of commodities. PAM is a product of two accounting identities, profitability, defined as the difference between revenue and cost while the other measure the effect of the divergencies (distorting policies and market failures) as the difference between observed parameters and parameters that would exist if the divergence were removed (Monke and Pearson [11]). The PAM is a framework for presenting the effect of policy and policy changes on incentives applied to production or marketing alternatives (Shapiro and Staal [12]). PAM is also used to measure input use efficiency, comparative advantage as well as competitiveness of production system given current technology, prices of input and output and policy (Nelson and Panggabean [13]).

According to Oluyole et al. [14], there are three cocoa production management systems. These are Owner-managed farms, Lease-managed farms and Sharecropped farms. These management systems are practiced across all cocoa producing regions in Nigeria. One fundamental issue is the approach to the understanding of how different farm management systems have implications on cocoa production. For this reason and other reasons, the theory of competitiveness has been utilised to analyse cocoa production management systems especially in this study.

The objective of this paper therefore is to assess the competitiveness and comparative advantage of cocoa production management systems in Nigeria. This is quite imperative in order to provide the indices that would be required to formulate cocoa policies that would be used to guide cocoa production in Nigeria.

\section{Methodology}

The project was carried out among cocoa farmers in Ondo and Osun States. Ondo and Osun States are major cocoa producing states in Nigeria. Two Local Government Areas (LGAs) were purposively selected from each State, thus making a total of four LGAs selected for the study. Twenty two respondents were randomly selected from each of the LGAs thus making a total of eighty-eight respondents that were randomly selected for the study. Simple random sampling technique was used to collect data from the farmers from the two states. Data were collected from the respondents with the aid of structured questionnaire and the data obtained from the questionnaire were analysed using descriptive analysis, Private Profitability, Private Cost Ratio, Social Profitability and Domestic Resource Cost.

Private Profitability $\prod=P_{0} Q_{O}-P_{i} Q_{i}$

Where:

$$
\begin{aligned}
\Pi & =\text { Private Profit }(\mathrm{N}) \\
\mathrm{P}_{\mathrm{o}} \mathrm{q}_{\mathrm{o}} & =\text { Value of output }(\mathrm{N}) \\
\mathrm{P}_{\mathrm{i}} \mathrm{q}_{\mathrm{i}} & =\text { Value of input }(\mathrm{N})
\end{aligned}
$$

Private Cost Ratio $P C R=\frac{\sum a_{i j} P_{k}{ }^{p}}{Y_{i}^{p} P_{i}^{p}-\sum a_{i j} P_{j}^{p}}$

Where:

$\Sigma \mathrm{a}_{\mathrm{ij}} \mathrm{P}_{\mathrm{k}}^{\mathrm{p}}=$ Value of domestic capital at private price $(\mathrm{N})$

$\mathrm{Y}_{\mathrm{i}}^{\mathrm{p}} \mathrm{P}_{\mathrm{i}}^{\mathrm{p}}=$ Value of output at private price $(\mathrm{N})$;

$\sum \mathrm{a}_{\mathrm{ij}} \mathrm{P}_{\mathrm{j}}^{\mathrm{p}}=$ Value of tradable inputs at private price $(\mathrm{N})$.

Social Profitability

$$
S P=\sum Y_{i}^{s} P_{i}^{s}-\left(\sum a_{i j} P_{j}^{s}+\sum a_{i j} P_{k}^{s}\right)
$$

Where:

$\Sigma Y_{i}^{s} P_{i}^{s}=$ Value of output at social price $(\mathrm{N})$;

$\Sigma \mathrm{a}_{\mathrm{ij}} \mathrm{P}_{\mathrm{j}}^{\mathrm{s}}=$ Value of tradable inputs at social price $(\mathrm{N})$; $\Sigma \mathrm{a}_{\mathrm{ij}} \mathrm{P}_{\mathrm{k}}{ }^{\mathrm{s}}=$ Value of domestic capital at social price $(\mathrm{N})$.

Domestic Resource Cost

$$
D R C=\frac{\sum a_{i j} P_{k}^{s}}{\sum Y_{i} P_{i}^{s}-\sum a_{i j} P_{j}^{s}}
$$

Where:

$\Sigma \mathrm{a}_{\mathrm{ij}} \mathrm{P}_{\mathrm{k}}^{\mathrm{s}}=$ Value domestic capital at social price (N);

$\Sigma \mathrm{Y}_{\mathrm{i}}^{\mathrm{s}} \mathrm{P}_{\mathrm{i}}^{\mathrm{s}}=$ Value of output at social price $(\mathrm{N})$;

$\Sigma \mathrm{a}_{\mathrm{ij}} \mathrm{P}_{\mathrm{j}}^{\mathrm{s}}=$ Value of tradable inputs at social price (N).

For ease of comparison of these indices, three cocoa production management systems were considered, these are Owner-managed farms, Lease-managed farms and Sharecropped farms. Owner-managed farms are the farms that are owned by the respondents themselves. These 
include the farms that are established or inherited by them. Lease-managed farms are the farms that are not owned by the respondents themselves but that are hired by the respondents for a period of time. During the period of hiring, all the proceeds from the farms belong to the respondents but the respondents would have to pay an agreed amount to the owner of the farms for hiring the farms for that period. Sharecropped farms are not owned by the respondents but the management of the farms is jointly carried out by the respondents as well as the owner of the farms. However, the proceeds from the farms would be jointly shared between the respondents and the owner of the farm.

\section{Results and Discussion}

Table 1. Socio-economic characteristics of the farmers

\begin{tabular}{|c|c|c|}
\hline Age (years) & & \\
\hline$\leq 30$ & 5 & 6.82 \\
\hline $30-50$ & 50 & 56.82 \\
\hline$>50$ & 32 & 36.36 \\
\hline Total & 88 & 100.00 \\
\hline \multicolumn{3}{|l|}{ Gender } \\
\hline Male & 71 & 80.68 \\
\hline Female & 17 & 19.32 \\
\hline Total & 88 & 100.00 \\
\hline \multicolumn{3}{|l|}{ Educational status } \\
\hline No formal education & 14 & 15.91 \\
\hline Primary education & 33 & 37.50 \\
\hline Secondary education & 30 & 34.09 \\
\hline Tertiary education & 11 & 12.50 \\
\hline Total & 88 & 100.00 \\
\hline \multicolumn{3}{|l|}{ Marital status } \\
\hline Singe & 2 & 2.27 \\
\hline Married & 82 & 93.18 \\
\hline Widow/widower & 4 & 4.55 \\
\hline Total & 88 & 100.00 \\
\hline \multicolumn{3}{|l|}{ Farm size } \\
\hline$\leq 5$ & 67 & 87.50 \\
\hline $5.1-10.0$ & 9 & 10.23 \\
\hline$>10.0$ & 12 & 2.27 \\
\hline Total & 88 & 100.00 \\
\hline
\end{tabular}

Source: Field survey, 2013.

The result of the socio-economic characteristics of the farmers is shown in Table 1. The table shows that $63.64 \%$ of the total respondents are of age 50 years and below. Hence, the greater proportion of the respondents is still in their active age. This is a good pointer to cocoa production efficiency as younger farmers are more active on farm work than the aged ones. Table 1 also shows that $80.68 \%$ of the respondents are males. This is quite obvious in that farm work is a tedious work and is only men that could cope effectively with it. As regards the educational level of the respondents, the result of the analysis shows that $84.09 \%$ of the respondents are having formal education. This would improve the efficiency of the farmers in as much that literate farmers would find it easier to adopt new technologies on cocoa than the illiterate ones. Table 1 also shows that $95.45 \%$ of the respondents are married. This however contributes significantly to family labour supply thus easing the problem of labour inadequacies for farm work in the area. The analysis on farm size shows that $87.50 \%$ of the respondents had farm size of 5 hectares which shows that majority of the farmers are small scale farmers.

The result of the competitiveness analysis as shown on table 2 showed that cocoa production is highly competitive in the three cocoa production management systems. This is because the Private Profitability (PP) is positive and the Private Cost Ratio (PCR) result is less than one in each of the three management systems. Considering the values of $\mathrm{PP}$, cocoa production in the three management systems is highly competitive since the values of PP are very high. However, cocoa production is more competitive in Owner management system because the value of Private Profitability is the highest among the three management systems $(205,353.20)$. This is followed by Leasehold management system with PP value of $80,340.38$ while the least is Sharecropping management system. The values of Private Cost Ratio showed that cocoa production in the three management systems is highly competitive, meanwhile, the lower the PCR the higher the competitiveness. Therefore, cocoa production in Owner management system is more competitive since it is having the lowest PCR. This is followed by Leasehold management system and the least is Sharecropping management system. Looking at the values of both the PP and PCR together, it clearly showed that cocoa production is more competitive in Owner management system than the other two management systems given current technologies, prices of inputs and outputs, and the prevalent government policy.

Table 2. Result on analysis on Competitiveness

\begin{tabular}{|c|c|c|}
\hline $\begin{array}{c}\text { Management } \\
\text { systems }\end{array}$ & $\begin{array}{c}\text { Private Profitability } \\
\text { (PP) }\end{array}$ & $\begin{array}{c}\text { Private Cost Ratio } \\
\text { (PCR) }\end{array}$ \\
\hline Owner & $205,355.20$ & 0.49 \\
\hline Leasehold & $80,340.38$ & 0.53 \\
\hline Sharecropping & $55,328.57$ & 0.54 \\
\hline
\end{tabular}

Source: Field survey, 2013

Table 3 shows the result of the analysis on Comparative Advantage of cocoa production in the three management systems. The results showed that cocoa production in Nigeria is having comparative advantage in the three cocoa production management systems. This is because the value of Social Profitability (SP) is positive and Domestic 
Resource Cost (DRC) is less than unity in each of the three management systems. Considering the value of SP, the table shows that cocoa production in Nigeria is having comparative advantage because of the high values of SP. It indicates that each of the management system uses scarce resources efficiently and contributes to national income (Nelson and Panggabean [13]; Keyser [15]), hence, the commodity has a static comparative advantage in the three management systems. However, Owner management system has the highest comparative advantage being the one that is having the highest value of SP $(188,962.00)$, this is followed by Sharecropping with SP value 48,705.29 while the least is Leasehold management systems. The values of DRC on the table (Table 3) shows that cocoa production in Nigeria is having high comparative advantage with the values of DRC far less than unity. It shows that the value of domestic resources used in cocoa production in the three management systems is lower than the value added. This implies an efficient use of domestic resources in production and that production is socially profitable (Oluyole [14]). However, cocoa production under Owner management system had the highest comparative advantage with the DRC value of 0.52 since the lower the value of DRC, the higher the comparative advantage. This is followed by Sharecropping management system with the DRC value of 0.59 and the least is that of Leasehold management system.

Table 3. Result of analysis on Comparative Advantage

\begin{tabular}{|c|c|c|}
\hline $\begin{array}{c}\text { Management } \\
\text { systems }\end{array}$ & $\begin{array}{c}\text { Social Profitability } \\
\text { (SP) }\end{array}$ & $\begin{array}{c}\text { Domestic Resource Cost } \\
\text { (DRC) }\end{array}$ \\
\hline Owner & $188,962.00$ & 0.52 \\
\hline Leasehold & $45,016.05$ & 0.68 \\
\hline Sharecropping & $48,708.29$ & 0.59 \\
\hline
\end{tabular}

Source: Field survey, 2013.

\section{Conclusions}

Majority of the respondents are formally educated and this is a good pointer towards high productivity and thus increases the competitiveness in cocoa production. Also, most cocoa farmers in the study area are small scale producers, this is because majority of the farmers are having farm size of five hectares and below. Cocoa production in the study area is highly competitive. However, cocoa production in owner management system is the most competitive of the three production management systems. Cocoa production in the study area is having a high comparative advantage. Hence, cocoa farmers in the study area utilize their resources efficiently to produce cocoa.

In as much that cocoa production in the study area is highly competitive and is having high comparative advantage, it is hereby recommended that government should give farmers incentives to expand their farms as majority of the farmers are small scale farmers (having less than 5 hectares of land). The incentives may include provision of soft loans as well as subsidized inputs.

\section{REFERENCES}

[1] Akinbola, C.A. (2001). International Projects on Cocoa Marketing and Trade in Nigeria. Manual on Cocoa Quality and Training Manual for Extension Workers pp: 10-24.

[2] Olayide, S.O. and A. Falusi, (1975). Economics of Cocoa Production. In Proceedings of International Cocoa Research Conference, Ibadan, Nigeria pp: 12-17.

[3] Oyinloye, J.P. (1999). Cocoa Marketing in Nigeria. In Cocoa Association of Nigeria Bulletin, Issued by the Secretariat of Cocoa Association of Nigeria (CAN), May 1999.

[4] Abbott, P. (2002). Towards More Socially Responsible Cocoa Trade. Working Paper \#03-3. International Agricultural Trade Consortium

[5] Ajayi, S.I. and T.A. Oyejide (1974). The Role of Cocoa in Nigeria's economic development. In Kotey R.A.C. Okala C. Okali and Rourke, (Eds.) The Economics of Cocoa Production and Marketing. Proceedings of Cocoa Economics Research Conference, Legon, Ghana, April 1973. 232, pp: 226-230.

[6] Titilola, S.T., (1997). An Econometric Model for Nigeria's Agricultural Sector with Emphasis on the Future of Cocoa in the Nigerian Economy (1970-1990) Ibadan: In Nigerian Institute of Social and Economic Research (NISER), pp: 16-19.

[7] Asare, R. (2005). Cocoa Agro-forests in West Africa: A Look at Activities on Preferred Trees in the farming system in Danish Centre for forest landscape and planning (KVL): 77

[8] Kaplinsky R. (2004). Competitions Policy and the Global Coffee and Cocoa Value Chains: Institute of Development Studies University of Sussex, and Centre for Research in Innovation Management, University of Brighton. kaplinsky@ids.ac.uk. Paper prepared for United Nations Conference for Trade and Development (UNCTAD).

[9] Mejabi Dayo (2012). The Nigerian Cocoa Value Chain: Vertical Coordination for Improved Productivity. Cocoa Round Table Workshop, Akure, 16th August, 2012.

[10] Oluyole, K.A., Taiwo, O., Shittu, T.R. and Yahaya, A.T. (2016). Economic Analysis of The Input Use Efficiency among Cocoa Farmers in Taraba State, Nigeria. Asian Journal of Agricultural Economics, Extension and Sociology. Vol. 8, Issue 4. Pp. 1-7.

[11] Monke, E. and Pearson, S.R. (1989). The Policy Analysis Matrix for Agricultural Development. Ithaca, N.Y., USA., Cornell University Press. Pp. 15-19.

[12] Shapiro B I and Staal, S.J. (1995) The Policy Analysis Matrix Applied to Agricultural Commodity Markets. In Gregory J. S. (Ed). Prices, Products and People. Analysing Agricultural Commodity Markets in Developing Countries. Lynne Publishers, London: Pp. 73-79. Togo.

[13] Nelson, G.C. and M. Panggabean (1991). The Cost of Indonesian Sugar Policy: A Policy Analysis Matrix 
Approach, Am. J. Agri. Econ., Vol. 73. No. 3. Pp. 703-712.

[14] Oluyole, K.A. J.M. Usman, O.A. Oni, O.O. Oduwole (2013). Input Use Efficiency of Cocoa Farmers in Ondo State, Nigeria. Journal of Finance and Economics, Vol. 1, No. 1, 8-10.
[15] Keyser, J.C. (2006). Description of Methodology and Presentation of Templates for Value Chain Analysis. Part 1: Narrative Text. Background paper for the Competitive Commercial Agriculture in Sub-Saharan Africa (CCAA) Study. 